\title{
Attitude of The Community Language of Bogor District towards Sunda Language: Sosiolinguistics Studies
}

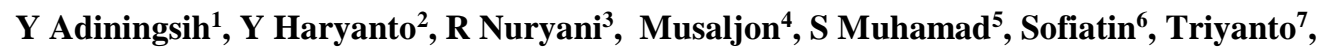 \\ R Maulinda ${ }^{8}$ \\ \{ ${ }^{1}$ yuliaadiningsih@ @tkipm-bogor.ac.id, ${ }^{2}$ haryanto@stkipm-bogor.ac.id, ${ }^{3}$ rinanuryani@ @stkipm- \\ bogor.ac.id, ${ }^{4}$ musa_muhammad@ @ stkipm-bogor.ac.id, ${ }^{5}$ sukardimuhamad@ @ stkipm-bogor.ac.id, \\ ${ }^{6}$ sofiatin_andih@stkipm-bogor.ac.id, ${ }^{7}$ triyanto@stkipm-bogor.ac.id, ${ }^{8}$ dosen00445@unpam.ac.id\} \\ 1,2,3,4,5,6,7 STKIP Muhammadiyah Bogor, Indonesia \\ ${ }^{8}$ Universitas Pamulang, Indonesia
}

\begin{abstract}
This research is motivated by the increasingly widespread people of Bogor Regency who rarely use Sundanese in every opportunity. The purpose of this study was to describe the attitudes of the people of Bogor Regency towards Sundanese viewed from (a) gender factors, (b) age factors, (c) type of work factors, and (d) level of education factors. The subjects of this research are the people who live in Bogor Regency. Data collection in this study uses the method of observation, questionnaires, and interviews. This study links the social characteristics of respondents with their opinions or justifications for Sundanese as a mother tongue. The results of this study about the attitudes of the people of Bogor Regency towards Sundanese viewed from (a) gender factors, the average value reached 69.24 according to either category. (b) the age factor average value reached 69 in the good category (c) factor type of work the average value reached 69.6 depending on the good category. (d) the level of education factor on average value reaches 69.16 close to either category. Based on these findings, it can be concluded that the language of the people of Bogor Regency has a good language attitude towards Sundanese.
\end{abstract}

Keywords: Language Attitude, Sundanese

\section{INTRODUCTION}

Language is the identity or characteristic of a society and even a nation. With language we can express ideas, ideas, and opinions. In addition to Indonesian, every region in Indonesia has its own regional language. That language is the identity of the community. A language is a communication tool used by humans in social life. Language is also a reflection, characteristics, and characteristics of a group of people. Each group of people has their cultural history and language, which is certainly different from one another. Indonesia has a variety of cultures and varied languages, one of which is Sundanese culture and language.

Sundanese is the mother language of the Sundanese with the second largest number of speakers with 27 million speakers [1]. Sundanese is spoken in almost all provinces of West Java and Banten. The dialect is varied. Speaking of dialects, until now there is still a long debate among fellow dialectologists about language and dialect. At first glance, the distinction between 
language and dialect is because conceptually, Dialect is a subdivision of language. In everyday reality on the ground, it is not as simple as one might imagine. It is not easy to determine the criteria that can be used to conclude that the two language variations found in Region X are two different languages or two different dialects of the same language. [2].

The existence of a language will be maintained if the speakers still preserve the language. As stated earlier, although Sundanese is the language with the second largest number of speakers after Javanese. However, that does not mean not threatened with extinction. The threat of the extinction of Sundanese is seen from the increasingly widespread use of Indonesian and Foreign languages which dominate the everyday conversation. In addition to that, [1] revealed the inability of young people to use regional languages, not apart from the influence of the increasingly strong existence of national languages. Indonesian which was originally only used in official situations, now has an informal situation, including its use in the family environment. As a result, Sundanese are less able to compensate for the dominance of national or foreign languages. This fact is exacerbated by the lack of a good assessment of local languages, one of which assesses that local languages are closely related to conservatives.

Research on Sundanese has been done by Khak. The study discusses the study of Language Shifting in Sundanese-Sundanese families in West Java. The results of the study are a shift in language among Sundanese people who are married to fellow Sundanese. In that study it was found that only $43.2 \%$ of the Sundanese parents' spouses taught Sundanese language to their children as a means of maintaining regional languages in the family. The language attitude of most Sundanese-Sundanese towards Sundanese is generally less positive because in their lives Sundanese is not too widely used. The less positive attitude of the language was also supported by an environment that did not provide much space for the use of Sundanese in everyday interactions, especially in heterogeneous regions, such as Depok, Bogor and Bekasi.[3]

Similar research has also been carried out by Saptarini et al., Who examined knowledge of language regulations and language attitudes of Sundanese rural communities in West Java. The results of this study are that in general the knowledge of rural Sundanese people in West Java about linguistic regulations can be categorized as poor because the average has only reached $34.25 \%$ of the ideal. Furthermore, the language attitude of the Sundanese Rural community in West Java can be categorized as good, because on average it reaches $68.56 \%$ of the ideal. [4]

This study discusses the language attitudes of the people of Bogor Regency towards Sundanese. What distinguishes this study from previous studies is that in this study the population is smaller and the sample taken is quite representative. So hopefully the results can be generalized.

The term attitude refers to the understanding of one's mental attitude. As stated by Schiffman in [5] "attitude is a learned disposition to behave inconsistently favorable or unfavorable way to reflect on a given object" attitude is a human tendency or tendency towards something. Attitude is an evaluation or assessment of objects, likes or dislikes become the core of that attitude. A person's attitude towards an object acts as an intermediary between the response and the object in question.

In line with this statement, [6] states attitude is a tendency to act following attitudes towards certain objects. Attitudes always exist in someone who appears through his behavior when dealing with certain objects.

Fishman stated that language attitudes are psychiatric events and are part of the attitudes of language users in general. Language attitude is an evaluation reaction to a certain language [8]. In agreement with that [9] revealed that the attitude of language (language Attitude) is a feeling or mental position towards one's language or the language of others. 
Garvin and Mathiot formulated three characteristics of language attitudes, namely: Language Loyalty that encourages the community of a language to maintain its language and if necessary prevent the influence of other languages. The pride of language (Language Pride) that encourages people to develop their language and use it as a symbol of identity and community unity. Awareness of the language norms (Awareness Of The Norm) that encourages people to use their language carefully and politely is a very big factor influencing the actions of activities using language. [10].

\section{RESEARCH METHODS}

This study uses a survey method, namely research that takes samples from the population and collects data through a questionnaire as a primary data collection tool. As Kerlinger said in the book [11] survey research is research conducted on large and small populations, but the data studied are data from samples taken from these populations, so that relative events, distribution, and relationships between variables are found. sociological and psychological. Survey research is usually done to generalize in-depth observations, but the generalization done can be more accurate when a representative sample is used.

The research subjects in this study were the people of western Bogor Regency. The determination of the sample using a quota proportional random sampling technique. The number of samples obtained as many as 130 people from 8 districts in Bogor Regency.

Data collection instruments in this study through observation, interviews, and questionnaires. Through the method of data collection obtained two types of data, namely qualitative data in the form of observations and interviews, and quantitative data in the form of a questionnaire or questionnaire data. Qualitative data were analyzed descriptively qualitatively using the analysis model proposed by Miles and Huberman in the book [12] which includes data reduction, data display, and conclusion drawing.

Furthermore, quantitative data obtained through a questionnaire or questionnaire method were analyzed descriptively quantitatively by involving several activities, namely classification based on gender, age, occupation, and education level. Convert answer choices into attitude categories, calculate frequency, and determine language attitude criteria. The following criteria for the interpretation of scores that the authors quote from [11]

Table 1. Score Interpretation Criteria

\begin{tabular}{cc}
\hline Skor & Interpretation Score \\
\hline $0 \%-20 \%$ & Not good \\
$21 \%-40 \%$ & Not good \\
$41 \%-60 \%$ & Enough \\
$61 \%-80 \%$ & Good \\
$81 \%-100 \%$ & Very good \\
\hline
\end{tabular}

\section{RESULTS AND DISCUSSION}

Tabel 2. The attitude of the Bogor Regency community language in terms of gender is

\begin{tabular}{llllll}
\multicolumn{7}{c}{ presented in the following table. } \\
\hline Variabel & Gender & $\mathrm{N}$ & Mean & Std. Deviation & categori \\
\hline Attitude & Male & 64 & 68,44 & 1,15 & Good \\
Language & Woman & 66 & 70,04 & 1,11 & Good
\end{tabular}




\begin{tabular}{|c|c|c|c|c|}
\hline Total & 130 & 69,24 & 1,13 & Good \\
\hline
\end{tabular}

From table 2 it can be seen that the attitude of the Bogor Regency community language in terms of male gender reaches 68.44 and can be categorized well. Furthermore, the attitude of Bogor Regency community language in terms of the gender of women reaches 70.04 and can be categorized well. In general, the attitude of Bogor Regency community language in terms of gender reached an average of 69.24 so that it can be categorized well. The attitude of the language of the female sex is better than the attitude of the language possessed by respondents who are male.

Tabel 3. The language attitudes of the people of Bogor Regency in terms of age are presented in the following table.

\begin{tabular}{llllll}
\hline Variabel & Age & $\mathrm{N}$ & Mean & $\begin{array}{l}\text { Std. } \\
\text { Deviation }\end{array}$ & categori \\
\hline Attitude & $<=30$ tahun & 66 & 69,1 & 1,1 & Good \\
Language & 31-40 tahun & 33 & 69,6 & 1,1 & Good \\
& 41-50 tahun & 16 & 70,2 & 1,2 & Good \\
& $>50$ tahun & 15 & 68,3 & 1,3 & Good \\
& Total & 130 & 69 & 1,2 & \\
\cline { 2 - 5 }
\end{tabular}

From table 3 it can be seen that the attitude of the Bogor Regency community language in terms of age $<=30$ years on average reaches 69.1 and can be categorized well. The language attitude of the people of Bogor Regency viewed from the age of 31-40 years reached 69.6 and can be categorized well. The attitude of Bogor Regency community language in terms of age 41-50 years reached 70.2 and can be categorized well. Furthermore, the attitude of Bogor Regency community language in terms of age> 50 years reached 68.3 and can be categorized well. In general, the attitude of Bogor Regency community language in terms of the average age reaches 69 so it can be categorized well. The attitude of languages aged between 41-50 years is better than the attitude of language that is owned by other respondents.

Tabel 4. The attitude of the Bogor Regency community language based on work is presented in the following table.

\begin{tabular}{llllll}
\hline Variabel & Job/Profesi & N & Mean & $\begin{array}{l}\text { Std. } \\
\text { Deviation }\end{array}$ & categori \\
\hline Attitude & Buruh Tani & 3 & 67,6 & 1,52 & Good \\
Language & Petani & 8 & 68,4 & 1,2 & Good \\
& Karyawan & 41 & 68 & 1,1 & Good \\
& Wiraswasta & 11 & 73,8 & 1 & Good \\
& Guru Honor & 13 & 73,9 & 1,1 & Good \\
& PNS & 6 & 67,2 & 1,3 & Good \\
& Ibu Rumah Tangga & 48 & 68,4 & 1,2 & Good \\
& Total & 130 & 69,6 & 1,2 & Good \\
\cline { 2 - 5 }
\end{tabular}

From table 4 it can be seen that the attitude of the Bogor Regency community language when viewed from the types of farm laborers works, on average it reaches 67.6, which means it is categorized as good. Bogor Regency people's language attitude seen from the type of work of farmers, an average of 68.4 which means that it is included in the good category. The attitude of the Bogor Regency community language when viewed from the type of work as employees, 
reached an average of 68 , which means it was categorized as good. The attitude of the language of the people of Bogor Regency is seen from the types of work as entrepreneurs, on average it reaches 73.8 which means it is categorized as good. The attitude of the Bogor Regency community's language is seen from the type of work as honorary teachers, on average it reaches 73.9 which means it is included in the good category. The attitude of the Bogor Regency community language when viewed from the type of work as civil servants, on average reaches 67.2 which means it is included in the good category. The attitude of the Bogor Regency community language when viewed from the type of work as a housewife, on average reaches 68.4 which means it is included in the good category. In general, the attitude of Bogor Regency community language when viewed from the type of work, an average of 69.6 which means that it is included in the good category. The best language attitude is shown by respondents who have a job as an honorarium teacher, which on average reaches 73.9 in the good category.

Tabel 5. The attitude of the Bogor Regency community language in terms of the level of education is presented in the following table.

\begin{tabular}{llllll}
\hline Variabel & Educational level & $\mathrm{N}$ & Mean & $\begin{array}{l}\text { Std. } \\
\text { Deviation }\end{array}$ & categori \\
\hline Attitude & Not in School & 4 & 68,7 & 1,2 & good \\
Language & SD & 17 & 69,4 & 1,2 & good \\
& SMP & 27 & 68 & 1,1 & good \\
& SMA & 58 & 69,3 & 1,07 & good \\
& Sarjana & 24 & 70,4 & 1,14 & good \\
& Total & 130 & 69,16 & 1,14 & good \\
\hline
\end{tabular}

From table 5 it can be seen that the attitude of the Bogor Regency community language in terms of the level of education that is not schooled or did not graduate from elementary school reaches an average of 68.7 which means it is categorized as good. The attitude of the Bogor Regency community language in terms of the level of education that has completed elementary school reaches an average of 69.4 which means it is categorized as good. Furthermore, the language attitude of the people of Bogor Regency in terms of the level of education that completes junior high school reaches an average of 68 which means it is categorized as good. The attitude of the Bogor Regency community language in terms of the level of education that graduated from high school reached an average of 69.3 which means it was in a good category. The attitude of the Bogor Regency community language in terms of the level of education that has graduated reached an average of 70.4 which means that it is in a good category. In general, the attitude of the Bogor Regency community language in terms of education level reached an average of 69.16 which means it was included in the good category. The attitude of the language of the people of Bogor Regency who have a college degree has the most superior language attitude compared to other respondents who did not graduate, reaching an average of 70.4, which means it is categorized as good.

The results of this study are the attitudes of the people of Bogor Regency towards Sundanese in the good category. This justifies the results of research by Saptarini et al. that, the language attitude of the people in West Java have a good language attitude [13].

\section{CONCLUSIONS}

Based on the results of the research described in the discussion it can be concluded that in general the attitudes of the language of the people of Bogor Regency towards Sundanese are in 
a good category because they reach an average of 69.25. The attitude of Bogor Regency community language in terms of gender reached an average of 69.24 so that it can be categorized well. The attitude of the Bogor Regency community language in terms of the average age reaches 69 so that it can be categorized well. The attitude of the Bogor Regency community language when viewed from the type of work, on average reaches 69.6 which means it is included in the good category. And the attitude of Bogor Regency community language in terms of education level reached an average of 69.16 which means it was included in the good category.

This research still needs to be developed, because the population and samples taken are only one part of the Bogor Regency area, namely only the western part. This research will be resumed by taking samples from all parts of Bogor Regency, especially those with heterogeneous populations.

\section{REFERENCES}

[1] C. Sobarna, "Bahasa Sunda Sudah di Ambang Pintu Kematiankah?," Makara, Sos. Hum., vol. 11, no. 1, pp. 13-17, 2007.

[2] M. R. M. T. Lauder, "Reevaluasi Konsep Pemilah Bahasa dan Dialek untuk Bahasa Nusantara," Makara, Sos. Hum., vol. 6, no. 1, pp. 37-44, 2002.

[3] M. A. Khak, "Pergeseran Bahasa (Language Shifting) dalam Keluarga Sunda-Sunda di Jawa Barat," 2013.

[4] D. Saptarini, Tri., Kajian Tentang Pengetahuan Peraturan Kebahasaan dan Sikap Bahasa Masyarakat Sunda Pedesaan di Jawa Barat. 2016.

[5] Sugiyono dan Sry Satriya Tjatur Wisnu Sasangka, Sikap Masyarakat Indonesia terhadap Bahasanya. Yogyakarta: Elmatera Publishing, 2011.

[6] Gerungan, Psikologi Sosiologi. Bandung: Eresco, 1987.

[7] A. dan L. A. Chaer, Sosiolinguistik Perkenalan Awal. Jakarta: Rineka Cipta, 2010.

[8] J. Fishman, National Language and languages of wider communication. London: OUP, 1971.

[9] H. Kridalaksana, Kamus Linguistik (edisi empat). Gramedia Pustaka Utama, 2013

[10] P. L. M. M. Garvin, The Urbanization of the Guarani Language. Mounton, 1985.

[11] Riduwan, Belajar Mudah Penelitian, 6th ed. Bandung: Alfabeta, 2009.

[12] Sugiyono, Memahami Penelitian Kualitatif. Bandung: Alfabeta, 2009.

[13] K. Saddhono and M. Rohmadi, "A Sociolinguistics Study on the Use of the Javanese Language in the Learning Process in Primary Schools in Surakarta, Central Java, Indonesia." Int. Edu. Stu., vol. 7 no.6 pp 25-30, 2014 